\title{
Akromioklaviküler eklem çıkığında artroskopik tedavi ve klinik sonuçlar
}

\author{
Arthroscopic treatment of acromioclavicular joint dislocation and \\ clinical results
}

Abdullah Demirtaş

İstanbul Medeniyet Üniversitesi Tıp Fakültesi, Ortopedi ve Travmatoloji Ana Bilim Dalı, İstanbul

\begin{abstract}
Akromioklaviküler (AK) yaralanması olan olgularda artroskopik olarak uygulanan düğme-ip askı sistemleriyle stabilizasyon, sıklıkla kullanılan güncel bir tedavi yöntemidir. Akut olgularda düğme-ip askı sistemi uygulamasının tek başına yeterli olduğunu bildiren çalışmalar olduğu gibi buna ek olarak biyolojik korakoklaviküler (KK) greft ve/veya AK horizontal tespit uygulanmasını öneren çalışmalar da bulunmaktadır. Kronik olgularda ise tendon grefti ile KK rekonstrüksiyonları düğme-ip askı sistemlerine ek olarak uygulanmakta, ayrıca AK eklemin horizontal tespitinin uygulanması da önerilmektedir. Akut veya kronik AK yaralanmasına düğme-ip askı sistemi \pm $\mathrm{KK} \pm$ AK tespiti uygulanan hastalarda en sık karşılaşılan ilk iki komplikasyon birbiriyle de ilişkili olan redüksiyon kaybı ve korakoid kırıklarıdır. Redüksiyon kaybı anatomik KK restorasyonlarının uygulanmasıyla azaltılabilmektedir. Korakoid kırık riskini azaltmak için ise korakoide açılan tüneli doğru pozisyonda, mümkün olan en küçük çap ve sayıda açmak önerilmektedir. Ayrıca greft ile KK rekonstrüksiyon yapılan olgularda greftin korakoid tabanı etrafından geçirilmesi korakoid kırı̆ı riskini azaltabilmektedir. Bu tedavi yöntemlerinde her ne kadar yüksek komplikasyon oranları bildirilse de genel olarak tatminkâr klinik sonuçlar elde edilmektedir. Bununla birlikte, artroskopik AK eklem stabilizasyonu ile ilgili yapılan çalışmaların çoğunluğunun az sayıda hastayla yapılmış ve kanıt seviyesi düşük çalışmalar olması, bu yaralanmaların tedavisiyle ilgili standart bir tedavi protokolünün oluşturulmasına engeldir. Daha kesin sonuçların elde edilmesi için çok sayıda hastayla yapılmış, prospektif ve randomize klinik çalışmalara ihtiyaç vardır.
\end{abstract}

Anahtar sözcükler: akromioklaviküler eklem; çıkık; artroskopik cerrahi; düğme-ip askı

$\mathrm{O}$ muz kuşağı yaralanmalarının yaklaşık \%9'unu akromioklaviküler (AK) eklem yaralanmaları oluşturmaktadır. ${ }^{[1]}$ Günümüzde akut, düşük dereceli

\begin{abstract}
Stabilization with arthroscopically applied button-rope suspension systems is the current treatment method that is frequently used in patients with acromioclavicular (AC) injuries. While there are studies reporting that the button-rope suspension system alone is sufficient in acute cases, there are also studies recommending the application of biological coracoclavicular (CC) graft and/or AC horizontal fixation. In chronic cases, CC tendon graft reconstructions are applied in addition to button-rope suspension systems, and horizontal fixation of the AC joint is recommended. The two most common complications in patients who underwent button-rope suspension $\pm \mathrm{CC} \pm \mathrm{AC}$ fixation for acute or chronic $\mathrm{AC}$ injury are loss of reduction and coracoid fractures, which are interrelated. Reduction loss can be reduced by the application of anatomical CC restorations. In order to reduce the risk of coracoid fracture, it is recommended to open the tunnel to the coracoid in the correct position, with the smallest possible diameter and number of tunnels. In addition, in patients undergoing $\mathrm{CC}$ reconstruction with a graft, passing the graft around the coracoid base may reduce the risk of coracoid fracture. Although high complication rates are reported in these treatment methods, generally satisfactory clinical results are obtained. However, the low level of evidence in the majority of studies on arthroscopic AC joint stabilization performed with a small number of patients prevents the establishment of a standard treatment protocol for the treatment of these injuries. Prospective and randomized clinical studies with a large number of patients are needed to obtain more precise results.

Key words: acromioclavicular joint; dislocation; arthroscopic surgery; button-rope suspension
\end{abstract}

(Rockwood 1 ve 2) AK eklem yaralanmalarının tedavisinde öncelikli olarak konservatif yöntemler tercih edilirken $^{[2]}$, yüksek dereceli (Rockwood 4, 5 ve 6) yaralan-

iletişim / Contact: Prof. Dr. Abdullah Demirtaş•E-posta / E-mail: drademirtas@hotmail.com

ORCID iD: Abdullah Demirtaş, 0000-0003-0833-0752

Geliş / Received: 28 Aralık 2021 • Kabul / Accepted: 22 Ocak 2022 
malarda cerrahi tedaviler tercih edilmektedir. ${ }^{[3]}$ Rockwood 3 yaralanmalarda ise konservatif veya cerrahi yöntemlerden hangisinin kullanılacağı hâlâ tartışma konusu olmaya devam etmektedir. ${ }^{[3]}$ Kronik, konservatif yöntemlerle tedavi edilemeyen semptomatik AK eklem yaralanmalarında ise cerrahi yöntemler ön plana çıkmaktadır. ${ }^{[4,5]}$

Literatürde, akut AK eklem yaralanmalarının cerrahi tedavisinde farklı implantlar kullanılarak çok sayıda teknik tariflenmiştir. Bu implantlar arasında Kirschner telleri, Bosworth vidaları ve kanca plakları geçmişte sıkça kullanılsa da gelişen komplikasyonlar (migrasyon, çıkarılma gereksinimleri, tespit kaybı, kırık, enfeksiyon ve benzeri) nedeniyle zamanla terk edilmeye başlanmış ve yerlerini yeni implantlara bırakmıştır. ${ }^{[6-8]}$ Günümüzde, AK yaralanmalarda stabilizasyonun korunması için en önemli yapıların korakoklaviküler (KK) bağlar olduğu düşüncesiyle bu bölgenin stabilizasyonunu sağlayan düğme-ip askı sistemleri geliştirilmiş ve kullanılmaya başlanmıştır (Şekil 1). ${ }^{[9-11]}$ Düğme-ip askı sistemleri, açılan tüneller yoluyla korakoid tabanının altına ve klavikulanın üzerine yerleştirilen düğme implantlarından ve bu implantları bağlayan emile-

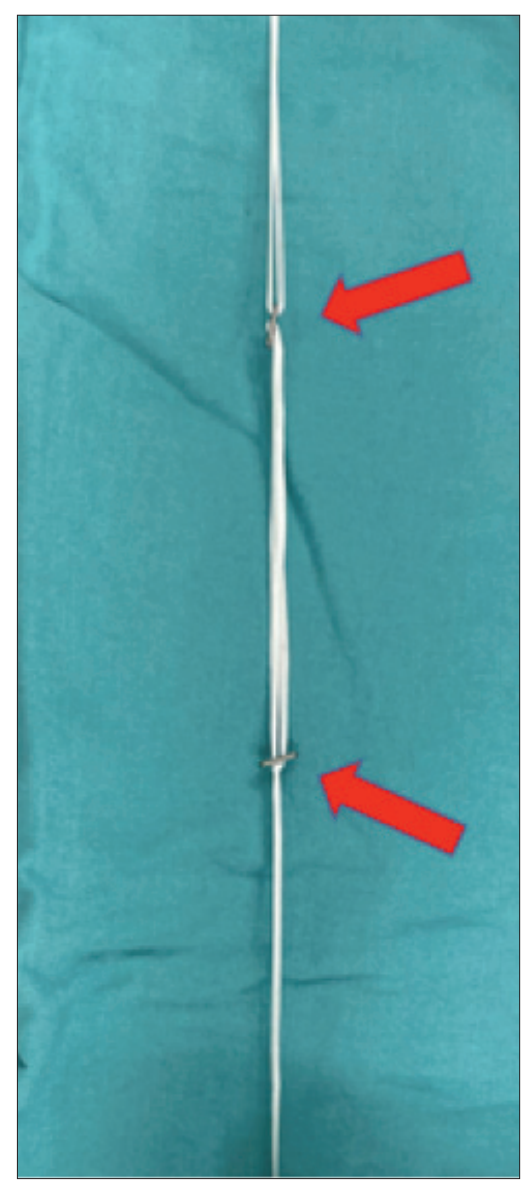

Şekil 1. Düğme-ip askı sistemi (Ok işaretleri: Düğme implantları). mez dikişlerden oluşan esnek bir sistemdir. Bu sistem, AK eklem yaralanmalarında ağırlıklı olarak vertikal stabiliteye katkıda bulunarak iyileşmeyi sağlar. ${ }^{[12]}$ Düğme-ip askı sistemleri klavikula üzerinde açılan iki tünel yardımıyla iki bağı (konoid ve trapezoid bağlar) da restore edecek şekilde anatomik olarak ${ }^{[11]}$ uygulanabildiği gibi klavikula üzerinde tek tünel yardımıyla konoid bağı restore edecek şekilde anatomik olmayan yöntemle ${ }^{[9]}$ de uygulanabilmektedir. Akut olgularda düğme-ip askı sisteminin tek başına yeterli olduğunu bildiren çalışmalar olduğu gibi ${ }^{[10]}$, buna ek olarak biyolojik KK greft ve/veya AK horizontal tespit uygulanmasını öneren çalışmalar da bulunmaktadır. ${ }^{[13]}$ Kronik yaralanmalarda düğme-ip askı sistemine ek olarak rekonstrüktif işlemlere ihtiyaç duyulmaktadır. Kronik yaralanmalarda geçmişte Weaver Dunn prosedürü yaygınlaşmış ve sıklıkla kullanılmıştır. ${ }^{[14]}$ Weaver Dunn prosedüründe klavikulanın distal 1/3'ü eksize edilir. Korakoakromial (KA) bağ, akromiona yapışma yerinden kesildikten sonra distal klavikulaya transfer edilir. Bu prosedür, daha sonra KA bağın akromiondan kemikli bir şekilde transferi sağlanarak farklı modifiye edilmiştir. ${ }^{[15]}$ Bununla birlikte, Weaver Dunn prosedürü ve modifikasyonu, tekrarlayıCı instabiliteye yol açabilmesi ve KA bağın sakrifiye edilerek korakoakromial ark devamlılı̆ının bozulmasının özellikle masif rotator manşet yırtıklı hastalarda oluşturabileceği potansiyel olumsuz sonuçları nedeniyle zaman içerisinde yaygınlığını kaybetmiștir. Günümüzde, kronik AK eklem yaralanmalarının tedavisinde düğme-ip askı sistemlerine ek olarak distal klavikula rezeksiyonu ve KK bağların tendon greftleri (semitendinozus, grasilis, peroneus ve benzeri otogreft/allogreftler) ile rekonstrüksiyonu sıklıkla tercih edilen yöntemlerdir. Ayrıca bu yaralanmalarda akut yaralanmalara göre vertikal instabiliteye belirgin olarak horizontal instabilitenin de eşlik ettiğinin gösterilmesiyle, son yıllarda AK ekleme de stabilizasyonunun eklenmesi gerekliliği vurgulanmaktadır. ${ }^{[16]}$

Akromioklaviküler eklem yaralanmalarında yukarıda bahsedilen uygulamalar günümüze kadar sıklıkla açık cerrahi girişimle yapılmaktaydı. Bununla birlikte invaziv diseksiyonun getirdiği yara problemleri ve kozmetik sorunlar, korakoide ulaşabilmek için delto-trapezial fasianın geniş bir şekilde klavikuladan ayrılma gereksiniminin rehabilitasyonu yavaşlatması, korakoid tabanının yeterince görüntülenememesinin nörovasküler yapılardaki yaralanma riskini artırması, yanlış tünel açılmasının kırık veya tespit kaybı riskini artırması, AK eklem yaralanmalarına eşlik eden glenohumeral eklem içi ve subakromial patolojilerin gözden kaçırılması gibi nedenlerle birçok cerrah son yıllarda açık cerrahi girişimler yerine artroskopik/artroskopi yardımlı girişimlere yönelmiştir. ${ }^{[4,5,17,18]}$ Aşağıda, başlangıçta konservatif yöntemlerle tedavi edilmesine rağmen semptomları geçmeyen, bunun üzerine travmadan 4,5 ay 


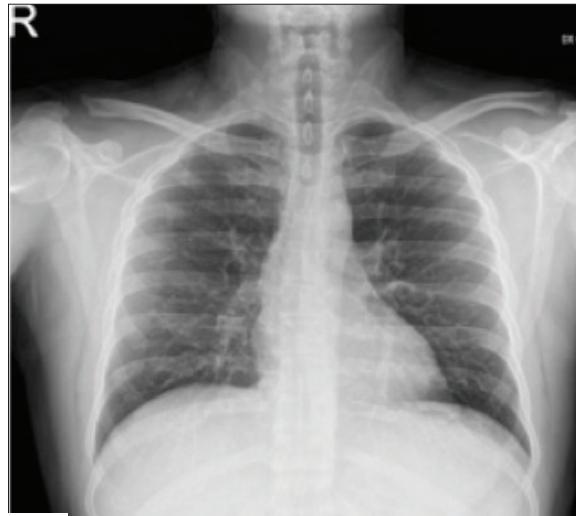

(a)
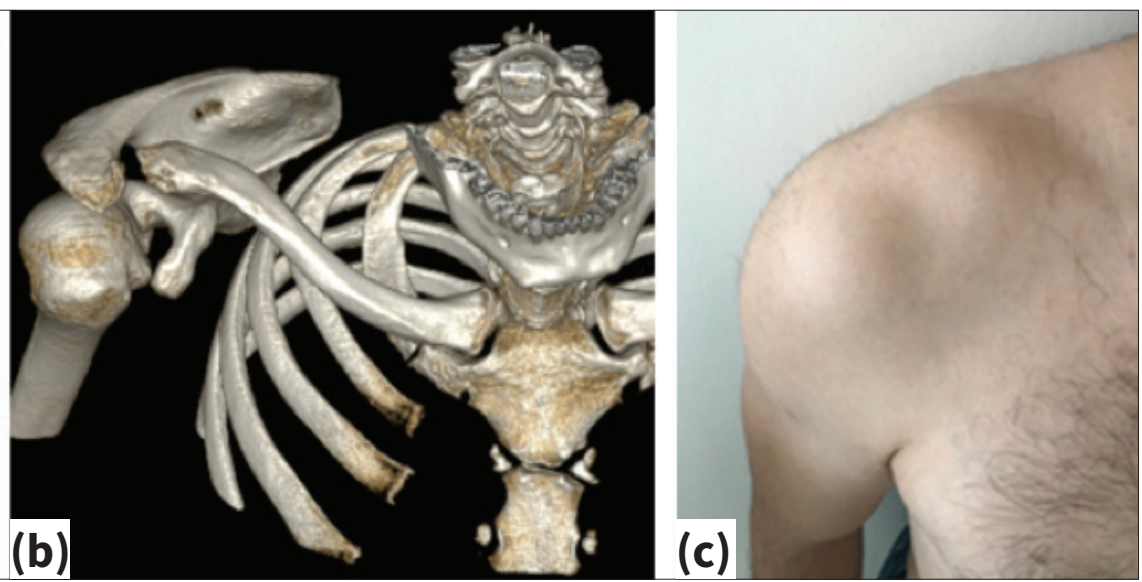

Şekil 2.a-c. 39 yaşında erkek hastanın sağ omuzundaki kronik akromioklaviküler eklem yaralanmasına ait görüntüler: $X$-ray (a). Üç boyutlu bilgisayarlı tomografi görünümü (b). Klinik görünümü (c).

sonra yazarın artroskopik cerrahi girişim uyguladığı kronik AK eklem yaralanması olan 39 yaşındaki bir olgusu (Şekil 2) üzerinden hem akut yaralanmalarda uygulanan düğme-ip askı sistem tespiti hem de kronik yaralanmalarda buna ek olarak uygulanan KK bağ rekonstrüksiyonu ve AK eklemin horizontal stabilizasyonuna dair Meislin ve ark.'nın uyguladığı teknik özetlenmiştir. ${ }^{[19]}$

\section{CERRAHI TEKNIK}

Hasta, genel anestezi altındayken şezlong pozisyonunda ameliyat masasına alınır, steril boyanır ve örtülür (Şekil 3). Ardından artroskopik portallere ait giriş yerleri steril boya kalemiyle işaretlenir (Şekil 4). Standart posterior $(P)$, portalden uygulanan artroskop yardımıyla öncelikle glenohumeral ekleme, ardından da subakromial alana girilerek AK eklem yaralanmasına eşlik eden eklem içi ve/ veya subakromial bölge patolojisinin olup olmadığı değerlendirilir. Ardından subskapularis tendonunun hemen

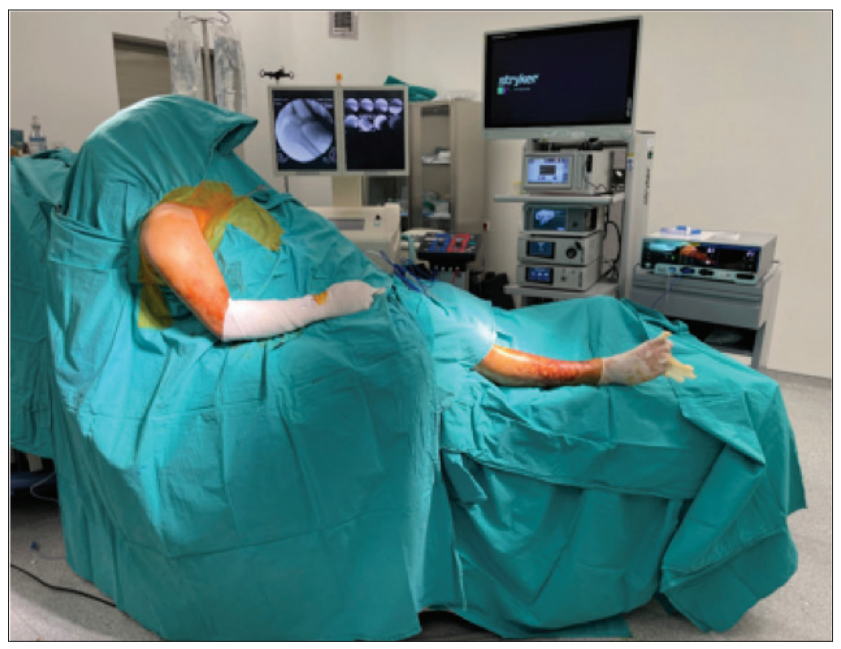

Şekil 3. Hastanın genel anestezi altında, şezlong poziyondaki görüntüsü. proksimalinde, korakoid çıkıntının medial ve hemen distalinde açılan anteromedial (AM) portalden glenohumeral ekleme girilir ve radyofrekans (RF) ve/veya shaver yardımıyla rotator interval debride edilerek korakoid çıııntıya ulaşılır. Korakoid çıkıntının alt kısmı yumuşak dokulardan temizlenerek görünür hale getirilir (Şekil 5). Bu aşamada

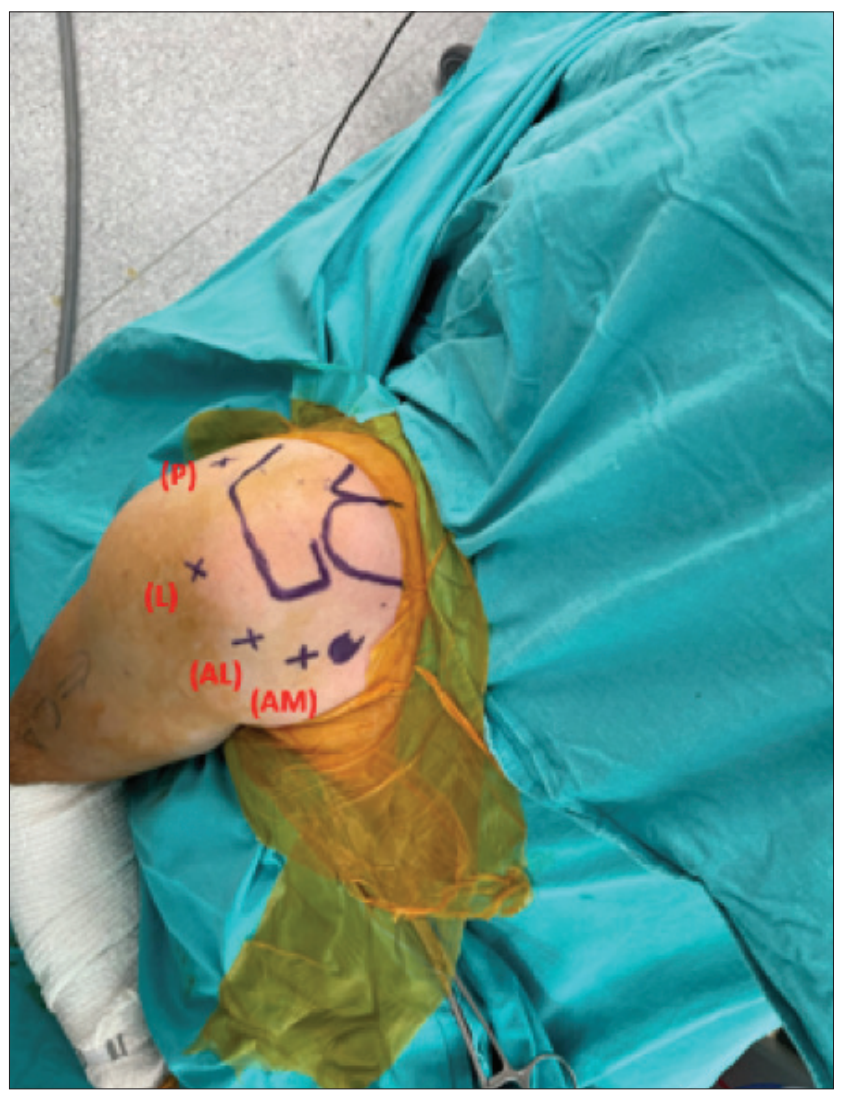

Şekil 4. Sağ omuzda artroskopik portallere ait giriş yerlerinin steril boya kalemi ile işaretlenmesi (P: Posterior, L: Lateral, AL: Antero-lateral, AM: Antero-medial). 


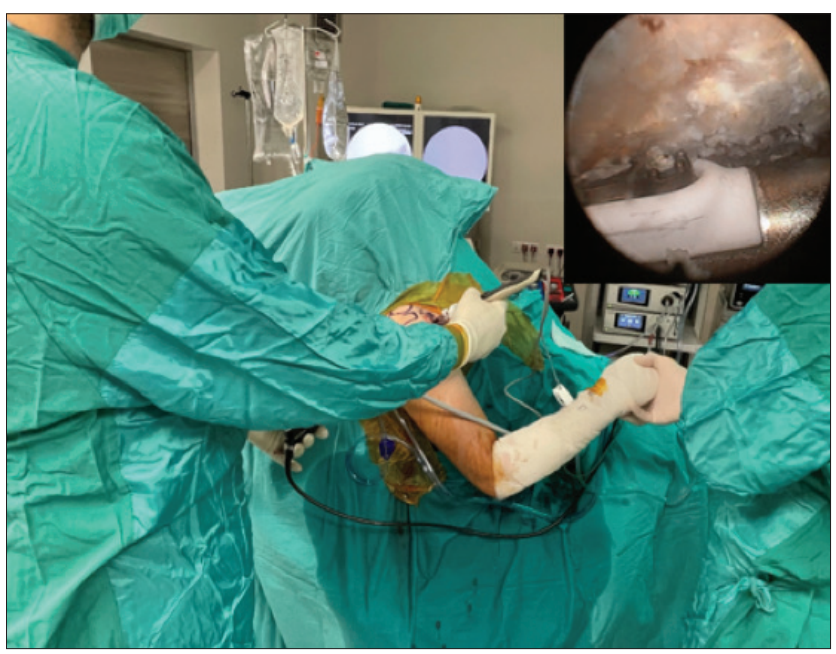

Şekil 5. Korakoid çıkıntının alt kısmının anteromedial portal yoluyla uygulanan shaver ile yumuşak dokulardan temizlenerek görünür hale getirilmesi.

$70^{\circ}$ lik artroskop ile daha iyi bir görüş alanı sağlansa da $30^{\circ}$ 'lik artroskop sıklıkla yeterlidir. Daha sonra, hem korakoidin tabanının alt kısmını daha iyi görüntülemek hem de özellikle kronik olgulardaki ligament rekonstrüksiyonu sırasında sütür taşıyıcıların geçirilmesi için antero-lateral (AL) portal açılır.

Daha sonra, AK eklemin $3 \mathrm{~cm}$ medialinde klavikulaya dik olacak şekilde yaklaşık $2 \mathrm{~cm}$ uzunluğunda cilt-cilt altı kesi yapılır, ardından delto-trapezial fasya klavikulanın superiorunda düğme implantının yerleşmesine izin verecek kadar gevşetilir (Şekil 6). Bu aşamada, kronik vakalarda eğer AK eklemin ameliyat öncesi değerlendirilmesi sırasında semptomatik artroz tespit edilmişse burr yardımıyla artroskopik olarak (gerekirse anteriordan ve lateralden ek portaller kullanarak) veya açık olarak 0,5-1 cm kadar distal klavikula rezeksiyonu yapılır (Yazarın bu olgusunda cerrahi öncesi değerlendirmede distal klavikulada osteoliz olması ve cross adduksiyon testinde ağrı tariflenmemesi, cerrahi sırasında ise cross adduksiyon testinde AK temas olmamasından dolayı rezeksiyona ihtiyaç duyulmamıştır). Daha sonra, AK eklem elle redükte edilir ve posterior ya da AL portalden uygulanan artroskop ile elde edilen görüntüleme eşliğinde korakoid ve klavikulada uygun tünel yerleşimi sağlamak üzere, dril hedefleme aparatının bir ucu AM portal yoluyla korakoid tabanının alt ucuna, diğer ucu klavikula üzerindeki ligamentlerin yapışma yerlerine sırasıyla yerleştirilir. Bu aşamada iki bağ (konoid ve trapezoid bağlar) stabilizasyonu yapılacaksa önce konoid sonra da trapezoid bağa ait tünel açılımı sağlanmalıdır. Konoid ligament stabilizasyonu için, hedefleme aparatının üst ucu AK eklemin 4,5 cm medialinde, klavikulanın superiorunda ön-arka çapın posterior $1 / 3$ 'lük kısmına yerleştirilmelidir. Daha sonra hedefleme aparatı içinde öncelikle klavuz

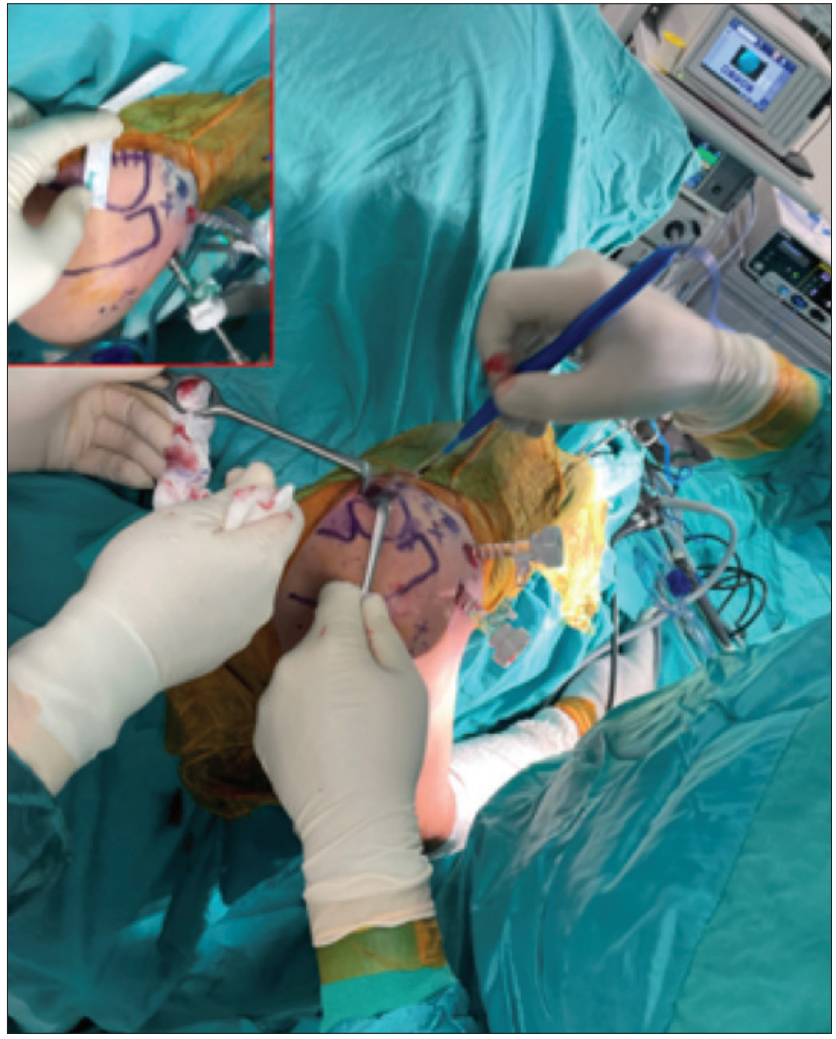

Şekil 6. AK eklemin $3 \mathrm{~cm}$ medialinde klavikulaya dik olacak şekilde yaklaşık $2 \mathrm{~cm}$ uzunluğunda cilt-cilt altı kesi yapılması, ardından delto-trapezial fasyanın koter yardımıyla klavikulanın süperiorunda düğme implantının yerleşmesine izin verecek kadar gevşetilmesi.

$\mathrm{K}$ teli klavikuladan korakoid tabanı alt kısmına doğru gönderilmeli, ardından da bu tel üzerinden 4,5 mm'lik kanüle dril kullanılarak klavikula ve korakoidde düğme-ip askı sisteminin geçirilmesi için gerekli tünel açılmalıdır. Trapezoid bağ stabilizasyonu için ise AK eklemin $2,5 \mathrm{~cm}$ medialinde, klavikulanın superiorunda, ön arka çapın orta 1/3'lük kısmı hedeflenecek şekilde hedefleme aparatı klavikulaya yerleştirilmeli ve konoid tünel açma işleminin benzeri burada da uygulanmalıdır. Korakoide açılan tünel sayısıyla ilgili olarak piyasada tek tünel üzerinden çift bağ stabilizasyonu sağlayan ürünler olduğu gibi iki ayrı korakoid tüneli üzerinden çift bağ stabilizasyonu sağlayan ürünler de bulunmaktadır. Yazar, birden fazla açılan tünellerin kırık riskine yol açabileceği endişesiyle korakoidde ve klavikulada birer adet tünel kullanılarak tek bağ stabilizasyonu sağlayan anatomik olmayan düğme-ip askı sistemlerini uygulamaktadır. Bu sistemde, klavikula tüneli AK eklemin yaklaşık $3 \mathrm{~cm}$ medialinde klavikula superiorunun ortasında olacak şekilde, korakoid tüneli ise korakoid tabanının alt kısmında, mediolateral planda ortada olacak şekilde açılmaktadır (Şekil 7). Tünel açılması sağlandıktan sonra $\mathrm{K}$ teli çıkarılır, kanüle dril ise yerinde bırakıı ve içerisinden nitinol tel gönderilir. Nitinol tel AM portalden sütür 


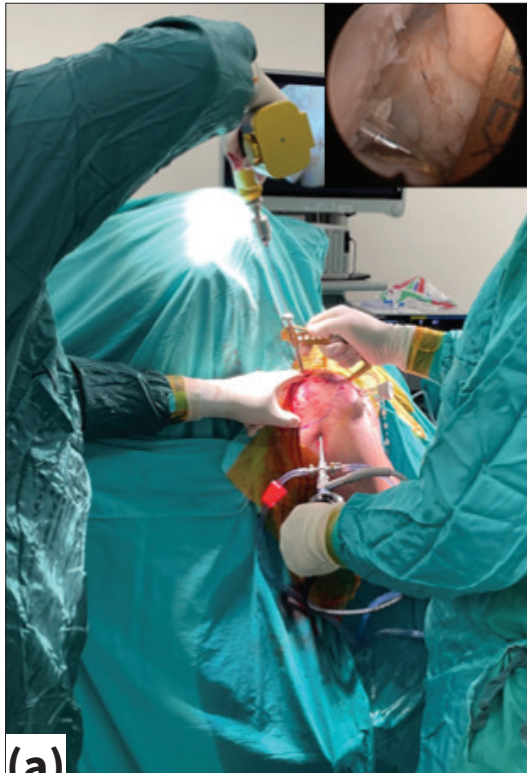

(a)
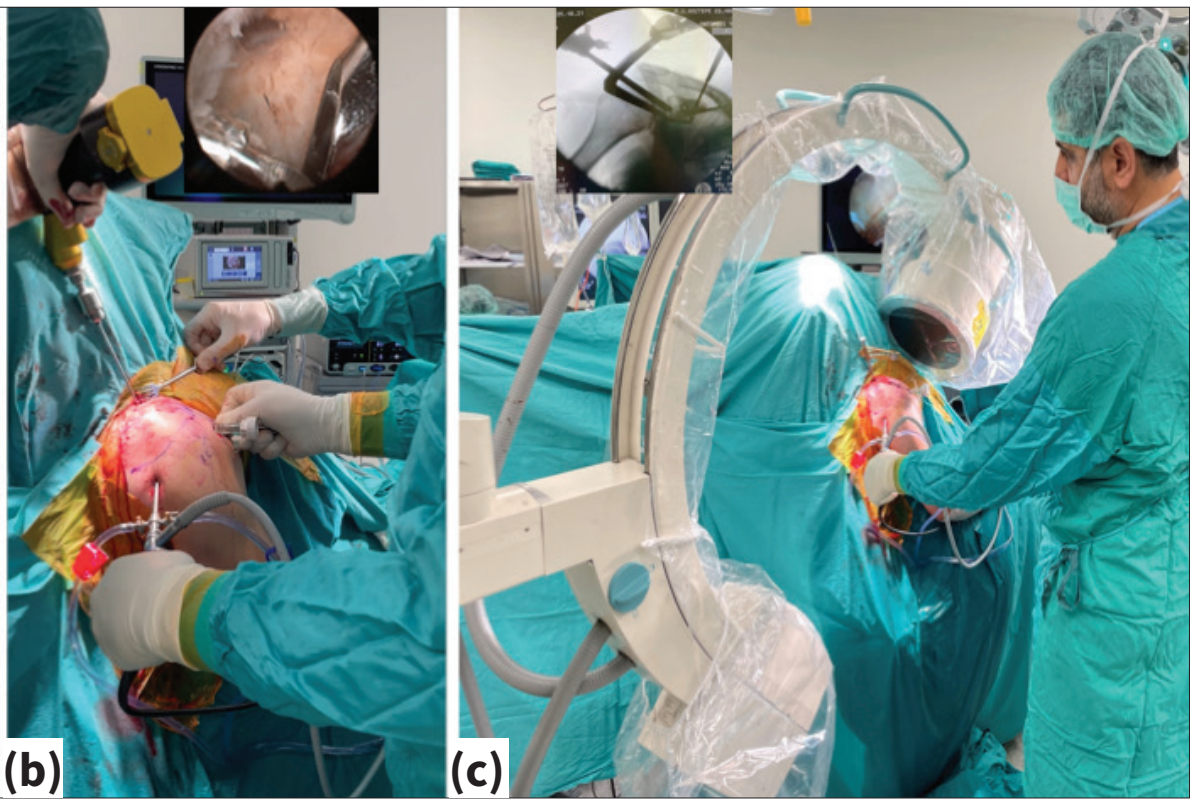

Şekil 7.a-c. Hedefleme aparatı içinden klavuz K telinin posterior ve antero-lateral portaller yoluyla uygulanan artroskopik görüntüleme eşliğinde klavikuladan korakoid tabanı alt kısmına doğru gönderilmesi (a). $\mathrm{K}$ teli üzerinden 4,5 mm'lik kanüle dril kullanılarak klavikula ve korakoidde düğme-ip askı sisteminin geçirilmesi için gerekli tünelin açılması (b). Skopi cihazının yerleşimi ve tünel açma basamakları sırasında işlemlerin skopi ile kontrol edilmesi (c).

tutucu veya klemp yardımıyla çıkarılır. Ardından klaviküler tarafta, nitinol telin loop (halka) şeklindeki üst ucuna düğme-ip askı sistemi yüklenir ve telin AM portalden çıkan alt ucu çekilerek düğme implantı distal ucunun korakoidin alt kısmından çıkarılması sağlanır. Böylece düğme-ip askı sisteminin bir ucu korakoid tabanının alt kısmında diğer ucu ise klavikula superioruna yerleştirilmiş olur (Şekil 8). Bu aşamada, akut vakalar için AK eklemin redükte pozisyonda olduğu skopi ile kontrol edildikten sonra klavikula superiorundaki düğme sistemi kilitlenerek düğümlenir ve böylece KK stabilizasyon ve dolayısıyla AK stabilizasyon sağlanmış olur.
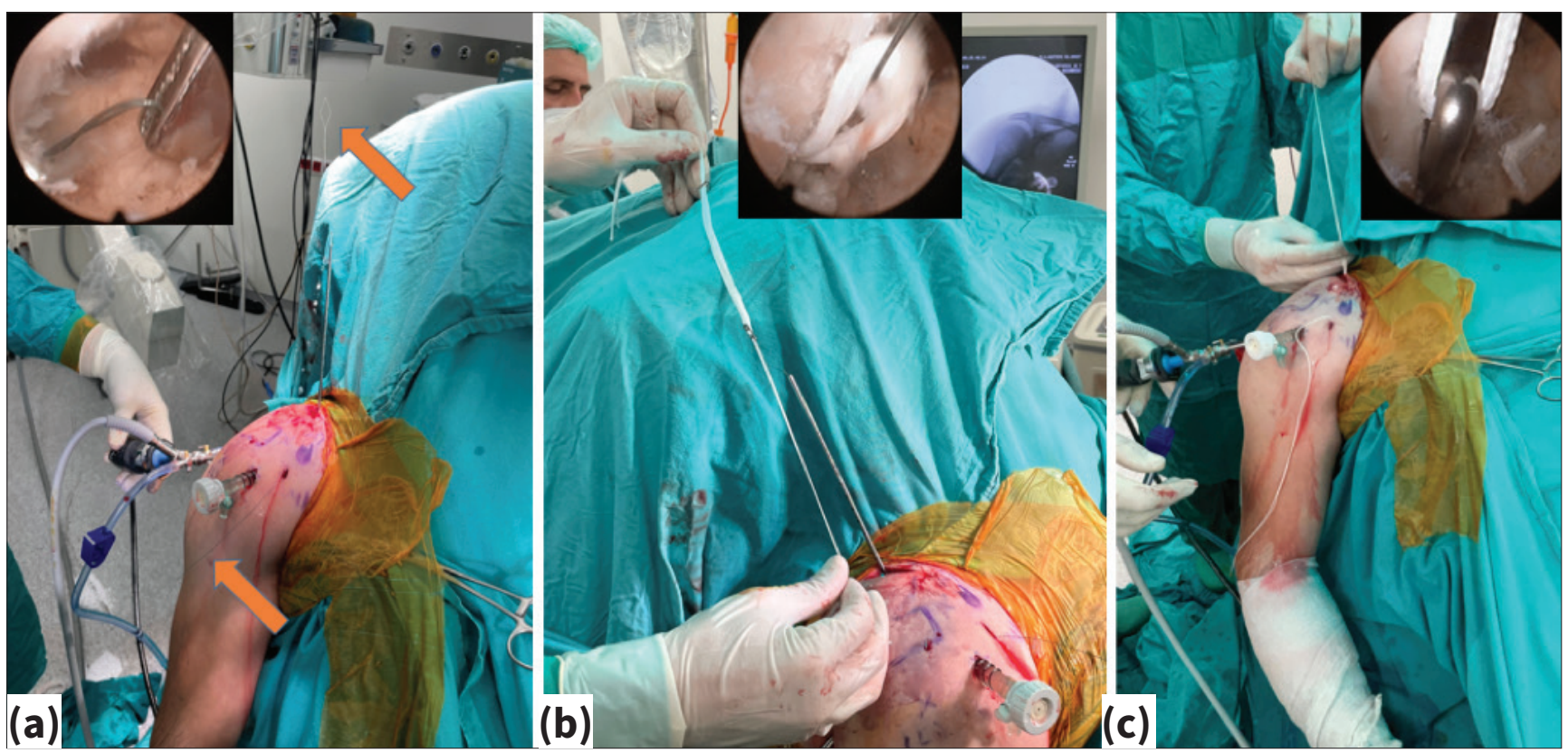

Şekil 8.a-c. Kanüle dril içinden nitinol telin anteromedial portalden klemp yardımıyla çıkarılması (Ok işaretleri: Nitinol telin proksimal ve distal kısımları) (a). Klaviküler tarafta, nitinol telin loop şeklindeki üst ucuna düğme-ip askı sisteminin yüklenmesi (b). Telin AM portalden çıkan alt ucu çekilerek düğme implantı distal ucunun korakoidin alt kısmından çıkarılması (c). 
Kronik vakalarda ise klavikula superiorunda düğme implantı kilitlenmez ve KK rekonstrüksiyon işlemine geçilir. Rekonstrüksiyon işlemi için öncelikle greft alınma işlemine geçilir. Yeterli uzunluğu sağlaması nedeniyle tercihen semitendinosis otogrefti elde etmek için tibia proksimalinde gerekli cerrahi prosedür uygulanır. Korakoklaviküler rekonstrüksiyonu için kanca şeklindeki sütür geçirici ya da bir klempin ucuna taşıyıcı iplik yüklenir. Daha sonra sütür geçirici ya da klemp, klavikulanın anteriorundan ilerletilir ve korakoid tabanının medialinden geçirilerek bir sütür yakalayıcı ya da klemp yardımıyla AL portale taşınır. Ardından ikinci bir taşıyıcı iplik sütür geçiriciye yüklenir ve yine klavikula anteriorundan ilerletilir ve korakoid lateralinden geçilerek bir sütür yakalayıcı ya da klemp yardımıyla AL portale taşınır. Antero-lateral portalden çıkarılan bu iki taşıyıcı iplik birbirine bağlanır. Daha sonra korakoid lateralinden geçen taşıyıcı iplik klavikula anteriorundan çekilir ve böylece korakoid tabanını loop şeklinde saran taşıyıcı iplik yerleştirilmiş olur. Ardından, AL veya posterior portale yerleştirilen artroskop görüntüsü eşliğinde klavikula anteriorundaki taşıyıcı ipin bir ucuna bağlanan greft taşıyıcı ipin diğer ucundan çekilerek korakoid tabanı altından geçirilir ve klavikula anterioruna taşınır. Böylece tendon grefti korakoid tabanını loop şeklinde sarmış olur
(Şekil 9). Ardından, bir klemp yardımıyla klavikula anteriorundan posterioruna doğru taşıyıcı bir ip geçirilir. Bu taşıyıcı ipin klavikula anteriorundaki ucuna tendonun bir ucu bağlanır ve posteriordaki ucu çekilerek tendonun bir ucunun klavikulanın posterioruna taşınması sağlanmış olur. Böylece korakoid tabanı altından loop şeklinde geçirilen tendon greftinin bir ucu klavikula anterioruna diğer ucu da klavikula posterioruna taşınmış olur. Daha sonra AK eklem skopi kontrolü altında elle redükte edilir ve klavikula üzerinde bulunan düğme implantı kilitlenerek dügümlenir. Ardından da klavikulanın anterior ve posteriorunda bulunan tendon uçları birbiri üzerinde düğümlenir. Dügümün açılmasını önlemek için destek sütürleri atılarak rekonstrüksiyon işlemi tamamlanır (Şekil 10). Böylece vertikal stabilite sağlanmış olur.

Horizontal stabilite için düğme implantı lateralinde klavikulaya bir adet düğümlü ankor gönderilir. Ardından akromionun üzerinde yaklaşı $1 \mathrm{~cm}$ uzunluğunda bir kesi yapılır. Bu kesi yoluyla bir adet klemp cilt altından ilerletilerek AK eklem medialindeki kesi yerine yönlendirilir. Düğümlü ankordan çıkan iplikler bu klemp yardımıyla çekilerek akromionun üzerinde yapılan kesi yerine taşınır. Ardından düğümsüz bir ankora yüklenen bu iplikler akromiona çakılır (Şekil 11). Böylece horizontal stabilite

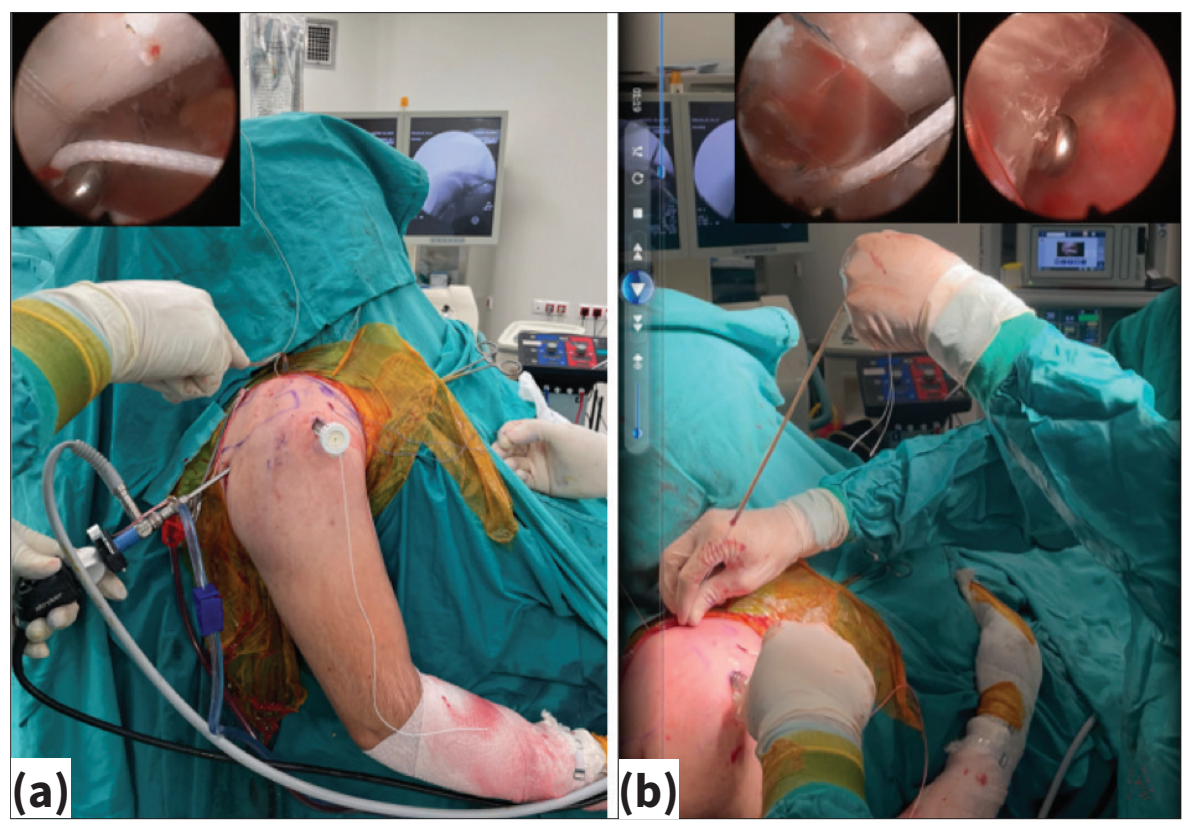

Şekil 9.a-b. KK rekonstrüksiyonu için taşıyıcı iplik yüklü kanca şeklindeki sütür geçiricinin klavikulanın anteriorundan ilerletilip korakoid tabanının medialinden geçirilmesi ve taşıyıcı ipliğin bir sütür yakalayıcı yardımıyla anterolateral portale taşınması, ardından ikinci bir taşıyıcı ipliğin sütür geçiriciye yüklenmesi ve yine klavikula anteriorundan ilerletilip korakoid lateralinden geçilerek bir sütür yakalayıcı yardımıyla anterolateral portale taşınması, anterolateral portalden çıkarılan bu iki taşıyıcı ipliğin birbirine bağlanması ve korakoid lateralinden geçen taşıyıcı ipliğin klavikula anteriorundan çekilerek korakoid tabanını loop şeklinde saran taşıyııı ipliğin yerleştirilmesi (a). Anterolateral veya posterior portale yerleştirilen artroskop görüntüsü eşliğinde klavikula anteriorundaki taşıyıcı ipin bir ucuna bağlanan greftin taşıyıcı ipin diğer ucundan çekilerek korakoid tabanı altından geçirilmesi ve klavikula anterioruna taşınması (b). 

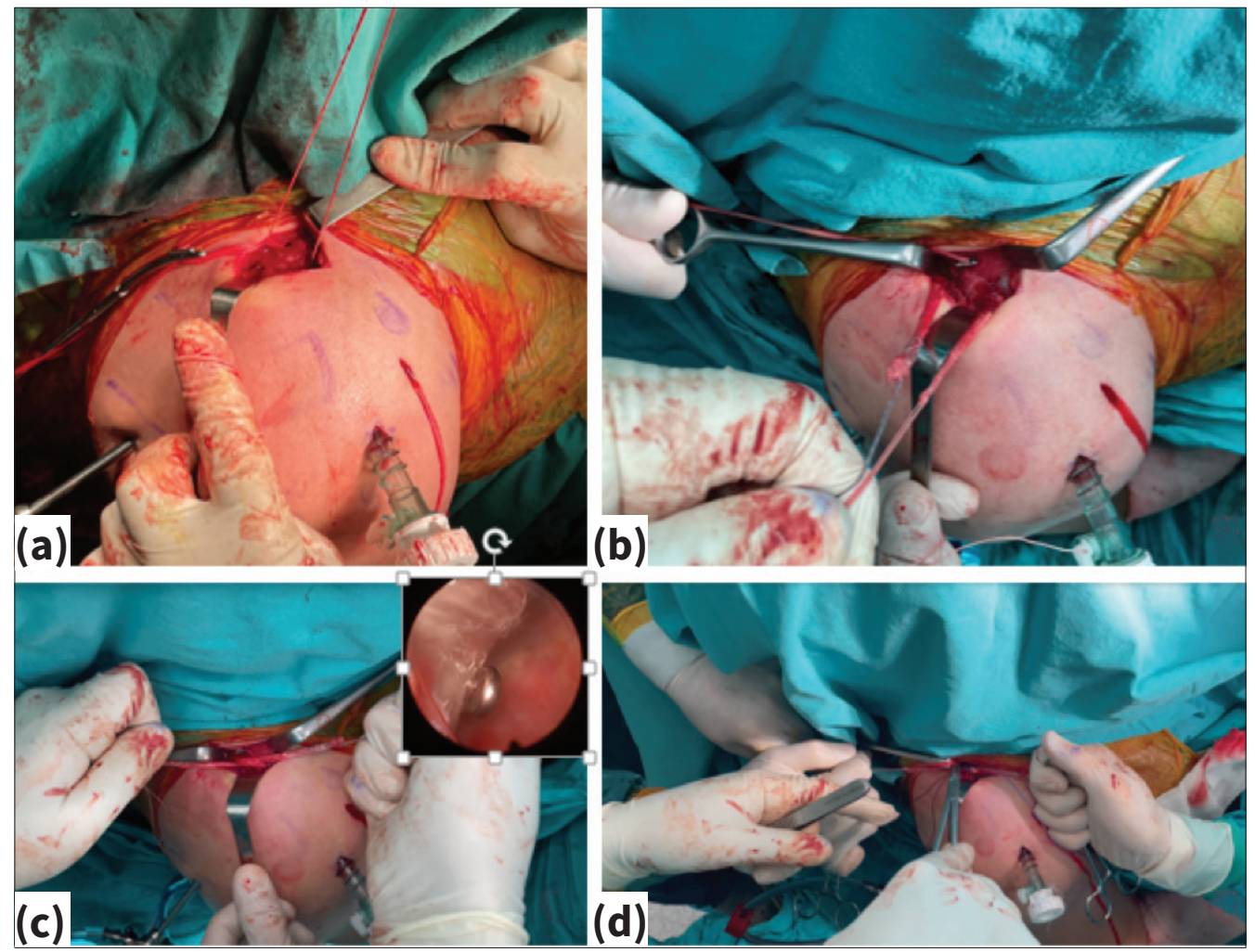

Şekil 10.a-d. Klavikula anteriorundan posterioruna doğru taşıyıcı bir ip geçirilmesi (a). Taşıyıcı ipe klavikula anteriorundaki tendonun bir ucunun bağlanarak klavikulanın posterioruna taşınması (b). Akromioklaviküler eklemin redükte edilmesinin ardından klavikula üzerinde bulunan düğme implantının kilitlenerek düğümlenmesi, ardından da klavikulanın anterior ve posteriorunda bulunan tendon uçlarının birbiri üzerinde düğümlenmesi (c). Dügümün açılmasını önlemek için destek sütürlerinin atılarak korakoklaviküler rekonstrüksiyon işleminin tamamlanması (d).
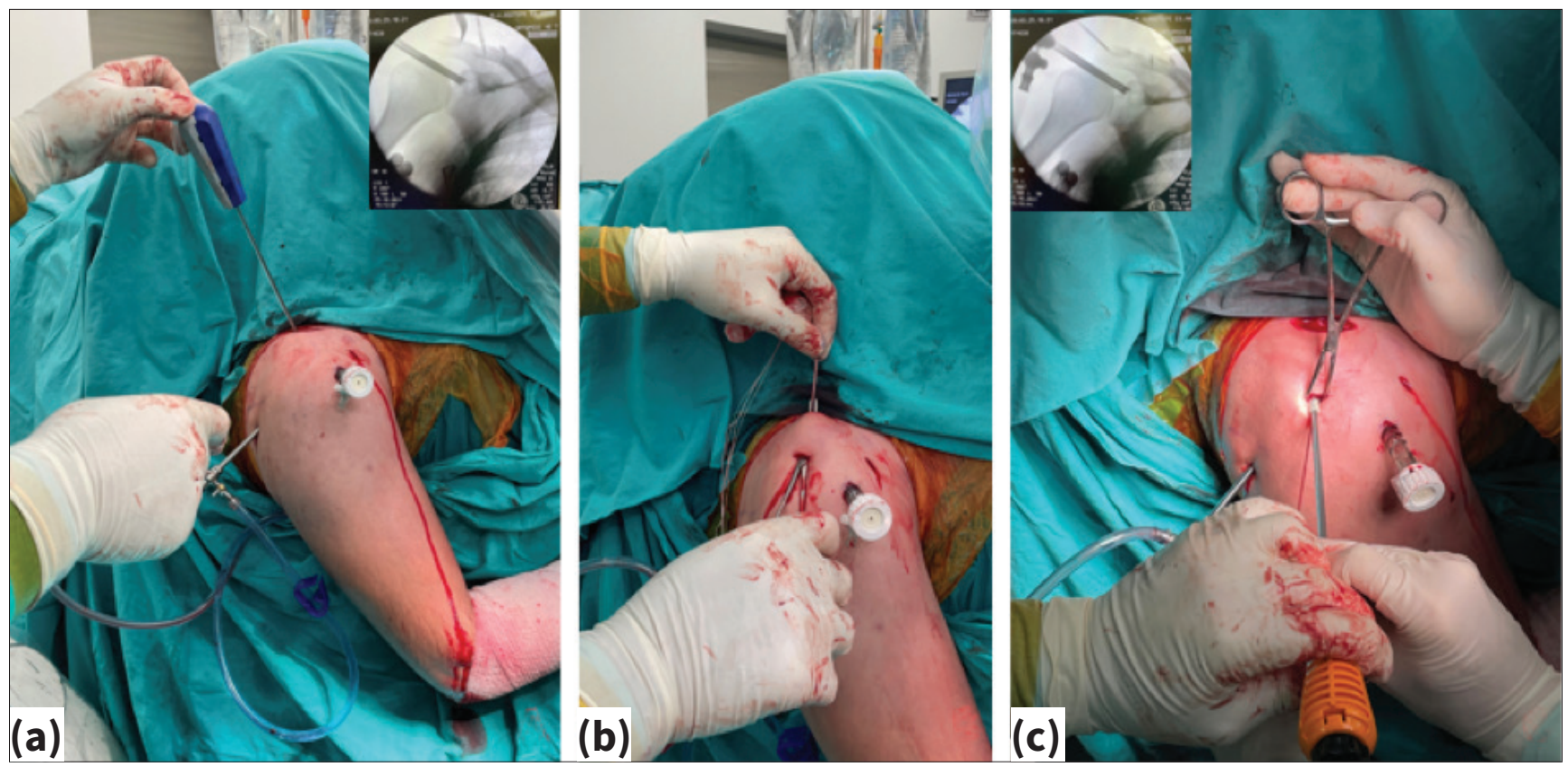

Şekil 11.a-c. Horizontal stabilite için; düğme implantı lateralinde klavikulaya bir adet düğümlü ankor gönderilmesi (a). Akromionun üzerinde yaklaşı $1 \mathrm{~cm}$ uzunluğunda bir kesi yapılması, bu kesi yoluyla bir adet klemp cilt altından ilerletilerek akromioklaviküler eklem medialindeki kesi yerine yönlendirilmesi, dügümlü ankordan çıkan ipliklerin bu klempin yardımıyla çekilerek akromionun üzerinde yapılan kesi yerine taşınması (b). Düğümsüz bir ankora yüklenen bu ipliklerin akromiona çakılması (c). 


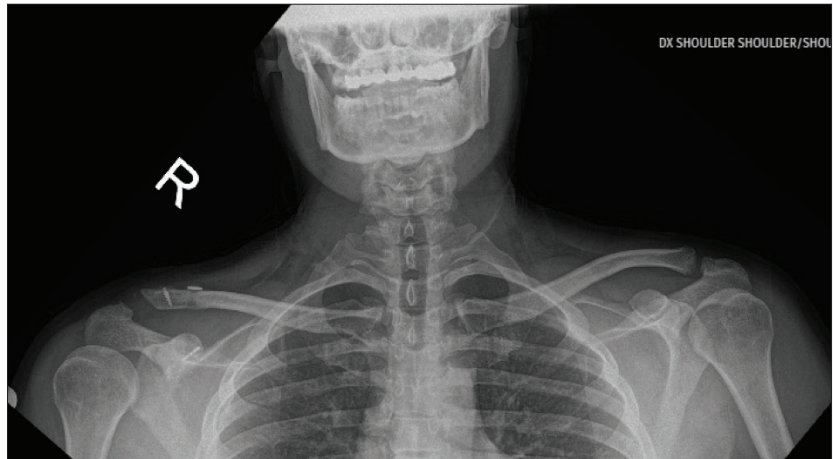

Şekil 12. Hastanın ameliyat sonrası erken dönemde çekilen her iki omuz karşılaştırmalı ön-arka X-ray görüntüsü.

sağlanmış olur. Horizontal stabilite sağlamak için bazı cerrahlar ankor-sütür yerine tendon grefti kullanmayı ve tespitin tenodez vidasıyla yapılmasını önermektedirler. Şekil 12'de hastanın ameliyat sonrası erken dönemde çekilen her iki omuz karşılaştırmalı ön-arka grafisinde AK eklemin stabilize edilmiş hâli gösterilmiştir.

\section{AMELIYAT SONRASI REHABILITASYON}

Rehabilitasyon programları değişken olmakla birlikte genel olarak 4-6 hafta omuz kol askısı kullanılır. Pasif hareket açıklığı egzersizlerine 4-6. haftalarda başlanır. Aktif hareket genişliği egzersizlerine altı haftadan sonra, güçlendirme egzersizlerine 8-12. haftalarda başlanır. Ağırlık kaldırmaya üçüncü aydan sonra, temas sporlarına ve tam aktiviteye dönüşe ise altıncı aydan sonra izin verilir. ${ }^{[10,18]}$

\section{SONUÇLAR}

Akromioklaviküler eklem yaralanmalarının tedavisi ile çok sayıda çalışmaya ait sonuç bildirilmekle birlikte bunların önemli bir kısmı az sayıda hastayla yapılmış olan kanıt düzeyi düşük çalışmalardır. ${ }^{[10-12,15,16]}$ Günümüzde, artroskopik yöntemler bu yaralanmaların tedavisinde giderek artan bir şekilde uygulansa da açık ya da artroskopik yöntemlerden hangisinin daha üstün olduğunu karşılaştıran az sayıda çalışma vardır. Genel olarak, artroskopik yöntemlerin klinik sonuç ve komplikasyonlar bakımından açık yöntemlere göre daha iyi sonuçları olduğu kabul edilmektedir. Bununla birlikte, Saccomanno ve ark. toplam 4206 olgunun değerlendirildiği sistematik derleme çalışmasında, akut AK yaralanması için biyolojik ve sentetik bağ rekonstrüksiyonu ya da osteosentez yapılan çalışmaları karşılaştırdılar ve açık teknikle yapılanlara göre artroskopik teknikle yapılan hastaların ortalama American Shoulder and Elbow Surgeons (ASES) skorlarının daha iyi, Visual Analog Scala (VAS) skorlarının daha düşük olduğunu, redüksiyon kaybı ve revizyon oranlarının ise şaşırtıcı olarak daha fazla görüldügünü bildirdiler. ${ }^{[20]}$ Çalışmada ayrıca, biyolojik ve sentetik rekonstrüksiyonlarda osteosentez tekniklerine göre daha iyi fonksiyonel sonuçların olduğu, en iyi Constant ve The Disabilities of the Arm, Shoulder and Hand (DASH) skorunun biyolojik rekonstrüksiyonlarda görüldüğü, sentetik askı sistemlerinin kendi içinde değerlendirildiğinde ise üç düğme-ip askı sistemi (anatomik) uygulananlarda iki düğme-ip askı sistemi (anatomik olmayan) uygulananlara göre daha iyi fonksiyonel sonuçlar elde edildiği bildirildi.

Güncel literatürde akut AK yaralanmaları için sıklıkla uygulanan artroskopik olarak düğme-ip askı sistemiyle stabilizasyon işlemi sonrasında zamanla redüksiyon kaybı, korakoid ve klaviküler düğmelerin yer değiştirmesi, korakoid ve klavikulada kırık, klavikula distalinde osteoliz, donuk omuz, refleks sempatik distrofi ve enfeksiyon gibi komplikasyonlarla karşılaşılabilindiği belirtilse de genel olarak ümit verici ve tatminkar klinik sonuçlar elde edildiği bildirilmektedir. ${ }^{[21-24]}$ Total komplikasyon oranları çalışmalarda $\% 20,7$ ile $\% 80$ oranlarında bildirilmektedir. ${ }^{[13,25,26]}$

Bu komplikasyonlar arasında en sık redüksiyon kaybı görülmektedir. ${ }^{[25]}$ Redüksiyon kaybı, klavikular tarafta tek tünel ile anatomik olmayan KK restorasyonun uygulandığı çalışmalarda \%16,6 ile \%50 oranında bildirilmiştir. ${ }^{[10,22-}$ ${ }^{24]}$ Biyomekanik olarak daha dayanıklı olan ve klavikular tarafta çift tünel ile anatomik restorasyonun uygulandığı düğme-ip askı sistemlerinde redüksiyon kaybı sorunu bir miktar giderilse de (anatomik olmayan sistemde restorasyonu yapılan konoid bağın tam olarak engelleyemediği posterior deplasmanın trapezoid bağın da restore edilmesiyle giderilmesi nedeniyle) hâlâ karşımıza çıkmaya devam etmektedir. ${ }^{[27,28]}$ Son yıllarda, redüksiyon kaybını azaltmak ve daha stabil bir tespit (fiksasyon) sağlamak için düğme-ip askı sistemlerine ek olarak tendon greftleri ile KK rekonstrüksiyon uygulamasının kronik vakalarda olduğu gibi akut vakalarda da uygulanmasını öneren çalışmalar bulunmaktadır. DeBerardino ve ark., iki düğme implantı arasına tendon greftinin yerleştirilerek geliştirilen anatomik olmayan sistemin (GraftRope, Arthrex, Naples, FL, ABD) sadece düğme-ip askı sistemine göre daha dayanıklı olduğunu ve biyolojik iyileşmeyi daha iyi sağladığını bildirdiler. ${ }^{[16]}$ Yazarlar, çalışmaya katılan 10 hastanın tamamının travma öncesi aktivite düzeyine ulaştıklarını ve bu süreçte herhangi bir redüksiyon kaybı veya komplikasyonla karşılaşmadıklarını bildirdiler. Buna karşın, Cook ve ark. ise askeri nüfusta GraftRope sistemini kullanarak tedavi ettikleri dokuz hastanın 10 omzunda \%80 oranında ameliyattan ortalama yedi hafta sonra redüksiyon kaybı geliştiğini, bunların yarısının revizyona gittiğini, hastaların sadece \%50'sinde mükem- 
mel/iyi sonuç elde ettiklerini, bir hastada korakoid kırı̆̆ı geliştiğini, dolayısıyla genç nüfusta bu yöntemin tercih edilmemesi gerektiğini bildirdiler. ${ }^{[26]}$ Redüksiyon kaybıyla ilgili yaşanabilen bu sorunlar risk faktörlerinin belirlenme ihtiyacını doğurmuştur. Sun ve ark.tünel lokalizasyonu, düğme yerleşimi ve osteoporoz varlığını redüksiyon kaybı için risk faktörleri olarak bildirdiler. ${ }^{[29]}$ Shin ve ark. ise düğme implantındaki yer değiştirmenin yetmezliğe (hastaların \%16,6'sı) ve dolayısıyla redüksiyon kaybına yol açabileceğini ancak düğme implantında herhangi bir yetmezlik olmadan da (hastaların \%17'si) \%50'den fazla redüksiyon kaybı olduğunu ve bu durumun, anatomik çift $\mathrm{KK}$ bağ restorasyonu yerine klavikulada anatomik olmayan tek KK bağ restorasyonu yapılmasından, horizontal stabilizasyon için AK eklemin restore edilmemesinden ve kemik-metal düğme arayüzü üzerinde yoğunlaşan aşırı stres nedeniyle klavikulanın erozyonundan kaynaklanabileceğini bildirdiler. ${ }^{[10]}$ Greft uygulanan hastalarda greft yırtılması ya da uzaması redüksiyon kaybının diğer nedenleri arasında sayılabilir. Literatürde, akut AK eklem yaralanmalarındaki redüksiyon kayıplarının önlenmesi için KK restorasyona ek olarak horizontal stabilitesinin artırılmasına yönelik girişimlerin yapıldığı az sayıda çalışma mevcuttur. ${ }^{[13,30]}$ Haoqing ve ark., akut AK yaralanması olan 10 hastanın tedavisinde çift düğme (korakoid ve klavikulaya birer tünel) ile anatomik olmayan KK bağ restorasyonunu AK bağ restorasyonu ile kombine ettiler ve sekiz hastada mükemmel-iyi sonuç bildirerek horizontal stabilitenin sağlanmasının gerekliliğine vurgu yapmışlardır. ${ }^{[30]}$ Barth ve ark. prospektif çok merkezli çalıșmasında 116 akut AK eklem yaralanması olan ve artroskopik olarak KK (hastaların \%93'ünde anatomik olmayan sistem ile) ve AK eklemin stabilizasyonu uygulanan hastaları incelediler. ${ }^{[13]}$ Çalışmada, AK stabilizasyon uygulanan hastalarda ameliyat öncesinde 4,15 mm olan AK mesafenin ameliyat sonrasında 0 mm'ye düşürüldüğü, bir yıllık takip sonucunda hastaların $\% 82$ 'sinde $\geq 85$ puan üzerinde Constant skoru elde edildiği, \%90 hastanın, "Aynı prosedürü tekrarlardım." demesine karşın çok tatmin ve tatmin olan hastaların oranının $\% 41$ olduğu bildirildi. Çalışmada ayrıca, hastaların \%20,7'sinde komplikasyon geliştiği, komplikasyon gelişen hastaların \%6,9'unda revizyon cerrahisine ihtiyaç olduğu bildirildi ve bu yaralanmalarda kullanılan implanttan bağımsız olarak tek başına KK stabilizasyonun yeterli olmadığı, iyi fonksiyonel sonuç için buna ek olarak AK horizontal stabilizasyonun da yapılması gerektiği vurgulanmıştır. Theopold ve ark. 21 insan kadavrasında oluşturdukları AK yaralanma modelinde üç ayrı grubun siklik (döngüsel) yüklenmeye karşı deplasman miktarlarını değerlendirdiler (1. gruba korakoid ve klavikulaya birer tünel [anatomik olmayan sistemle bağ restorasyonu] ile AK serklaj sütür kombinas- yonu, 2. gruba korakoid ve klavikulada ikişer tünel [anatomik sistemle bağ restorasyonu], 3. gruba ise korakoid ve klavikulaya ikişer tünel [anatomik sistem ile bağ restorasyonu] ile AK serklaj sütür kombinasyonu uygulandı). ${ }^{[31]}$ Çalışmada, 1 . grupta, 2 ve 3 . gruba göre total deplasman miktarı anlamlı derecede daha yüksek bulunurken 2 ve 3 . gruplar arasında anlamlı bir fark saptanmadığı, dolayısıyla korakoid ve klavikulaya ikişer tünelin açıldığı anatomik bağ restorasyonunun uygulandığı vakalarda ek olarak AK serklaj sütüre gerek olmadığı bildirildi. Banffy ve ark. ise 18 insan kadavrası ile yapmış olduğu çalışmasında anatomik ve anatomik olmayan KK bağ restorasyonu yapılan olgularda superior, anterior ve posterior deplasman açısından anlamlı bir farkın olmadığını, anatomik olmayan sistemin klavikular kırık riski açısından daha avantajlı olduğunu bildirdiler. ${ }^{[32]}$ isster anatomik olmayan, ister biyomekanik olarak daha güçlü olan anatomik düğme-ip askı sistemleri kullanılsın, radyolojik redüksiyon kaybı can sıkıcı bir komplikasyon olarak karşımıza çıksa da aslında her zaman klinik ve fonksiyonel olarak anlamlı bir kayba neden olmamaktadır. ${ }^{[10,33]}$ Shin ve ark., yukarıda bahsedilen 18 hasta ile yaptıkları çalışmalarında, hastaların \%33'ünde ameliyattan üç ay sonra karşı omuza göre $\% 50$ 'den fazla zamanla redüksiyon kaybı geliștiğini, buna rağmen hastalarda tatmin edici klinik sonuçlar (ameliyat sonrası altıncı ayda ortalama Constant skoru= 95,6) elde ettiklerini bildirdiler. ${ }^{[10]}$ Murena ve ark.'da artroskopik KK çift flip button ile tedavi ettikleri akut AK yaralanması olan 16 hastanın 1/4'ünde radyolojik olarak redüksiyon kaybı gözlenmesine rağmen ortalama Constant skorunun 97 olduğunu bildirdiler. ${ }^{[34]}$

Korakoid ve klavikula kırıkları, düğme-ip askı sistemi uygulanan hastalarda görülen bir diğer komplikasyondur. ${ }^{[24]}$ Çalışmalarda korakoidde \%20'ye, klavikulada ise \%18'e varan oranlarda kırık gelişebildiği bildirilmiştir. [24,35,36] Literatürde kırık oluşmasının birçok faktöre bağlı olabileceği gösterilmiştir. Korakoid tabanına veya klavikulaya birden fazla tünel açılması kırık riskini artırmaktadır. ${ }^{[37]}$ Korakoid veya klavikulada açılan tünellerin zamanla genişlemesi de kırık riskini artırır. Bununla birlikte tünel genişlemesi sıklıkla redüksiyon kaybına neden olmamaktadır. ${ }^{[38]}$ Başlangıçta geniş açılan tüneller de kırık riskini artırmaktadır. 2,4 mm yerine $4 \mathrm{~mm}$ tünel açıl-

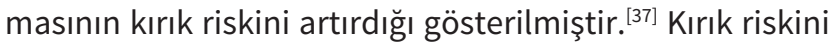
artıran bir diğer faktör de eksantrik yerleşimli tünellerin açılmasıdır. ${ }^{[10]}$

Akut AK yaralanmalarda olduğu gibi kronik yaralanmalarda da literatürde birbirinden farklı komplikasyonlar ve klinik sonuçlar bildirilmiştir. Kronik olgularda görülen komplikasyon oranları çalışmalarda \%27 ile \%52 oranında bildirilmiştir. ${ }^{[24,35]} \mathrm{Bu}$ komplikasyonların çoğu 
akut yaralanmalardakine benzerdir. Bununla birlikte düğme-ip askı sistemine ek olarak uygulanan greftle ilgili veya greft için açılan tünellerin daha geniş olması veya ek tünel açılma gereksiniminin korakoid ve/veya klavikulada oluşturacağı kırık riskiyle ilgili komplikasyonlar bu yaralanmalarda daha sık olarak karşımıza çıkabilmektedir. Motta ve ark. GraftRope tekniğini uyguladıkları ve en az yedi yıl takipli 12 kronik yaralanmalı hastada iyi redüksiyon elde ettiklerini, hastaların hepsinin travma öncesi işine ve sportif aktivitelerine dönebildiklerini, ortalama Constant skorunun 98,3 olduğunu, üç hastada ciddi AK artrit geliştiğini, bunlardan birisinde klinik sonucu olumsuz etkileyen gece ağrısının olduğunu, sekiz hastada radyolojik ossifikasyonların geliştiğini ama bunların kliniği olumsuz etkilemediklerini bildirdiler. ${ }^{[39]}$ Nordin ve ark. ise kronik AK yaralanmasına GraftRope tekniği uyguladıkları sekiz hastanın dördünde bir yıl içinde komplikasyon (üçünde korakoid kırığı, birinde ise greft yetmezliği nedeniyle redüksiyon kaybı) gelişmesi üzerine çalışmalarını yarıda bırakarak sonlandırdıklarını bildirdiler. ${ }^{[40]}$ Çalışmada ayrıca, redüksiyon kaybı olan hastalardan birinde ciddi ağrı ve fonksiyon kaybı gelişmesi nedeniyle revizyon uygulandığı, komplikasyon gelişmeyen dört hastanın üçünde mükemmel sonuç elde edildiğini, bu hastaların travma öncesi aktivite düzeylerine eriştiklerini, bir hastada ise ağrılarının devam ettiğini bildirdikten sonra korakoide greft yerleştirilmesi için açılan $6 \mathrm{~mm}$ kalınlığındaki tünelin kırık gelișmesi açısından güvenli olmadığını belirttiler. GraftRope tekniği dışında düğme implantı olmaksızın sadece allogreft ile KK rekonstrüksiyon uyguladıkları 12 kronik AK yaralanması olan hastadan oluşan çalıșmalarında VanSice ve ark., 10 hastada (\%83) mükemmel sonuç bildirdiler. ${ }^{[41]}$ Ayrıca çalışmada, toplamda \%25 oranında komplikasyon geliştiği, komplikasyonlar arasında en sık $(\% 16,6)$ redüksiyon kaybının görüldüğü bildirildi. Literatürde ayrıca, düğme-ip askı sistemi için açılan tünele ek olarak, greftin korakoide açılan ayrı tüneller yoluyla uygulandığg ${ }^{[42]}$ ) çalışmalar olduğu gibi son yıllarda korakoide açılan tünelin kırığa yol açma riskini azaltmak için greftin korakoid tabanı etrafından geçirilerek uygulandığı çalışmalar da bulunmaktadır. ${ }^{[18,43]}$ Benzer şekilde klavikula tarafında da greftin tünelden geçirilip tespit edildiği çalışmalar ${ }^{[18,43]}$ ya da klavikula etrafından geçirildiği çalışmalar ${ }^{[19]}$ mevcuttur. Bu makalenin yazarı, kendi pratik uygulamasında, düğme-ip askı sistemi için açılan tüneller haricinde tendon geçirilmesi için açılacak ek tünellerin korakoid ve/veya klavikulada kırık riskini artıracağı endişesiyle KK rekonstrüksiyon uygulaması sırasında tendonu korakoid tabanı ve klavikula etrafından geçirerek uygulamayı tercih etmektedir.

Sonuç olarak, AK yaralanması olan olgularda hangi yöntemin kullanılacağı konusunda tam bir görüş birliği olmasa da artroskopik olarak uygulanan düğme-ip askı sistemleri sıklıkla kullanılan güncel tedavi yöntemidir. Akut olgularda düğme-ip askı sisteminin tek başına yeterli olduğunu bildiren çalışmalar olduğu gibi buna ek olarak biyolojik KK greft ve/veya AK horizontal tespit uygulanmasını öneren çalışmalar da bulunmaktadır. Kronik olgularda ise KK tendon grefti rekonstrüksiyonları düğme-ip askı sistemlerine ek olarak uygulanmakta, ayrıca AK eklemin horizontal tespitinin uygulanması önerilmektedir. Akut veya kronik AK yaralanmasına düğme-ip askı $\pm \mathrm{KK} \pm \mathrm{AK}$ tespit uygulan hastalarda en sık karşılaşılan ilk iki komplikasyon çoğu zaman birbiriyle de ilişkili olan redüksiyon kaybı ve korakoid kırıklarıdır. Korakoid kırık riskini azaltmak için korakoide açılacak tüneli doğru pozisyonda, mümkün olan en küçük çapta ve sayıda açmak önerilmektedir. Korakoklaviküler greft uygulanacak hastalarda greftin korakoid tabanı etrafından geçirilmesi kırık riskini azaltabilmektedir. Bu tedavi yöntemlerinde her ne kadar yüksek komplikasyon oranları bildirilse de genel olarak tatminkar klinik sonuçlar elde edildiği görülmektedir. Bununla birlikte artroskopik AK eklem restorasyonu ile ilgili yapılan çalışmaların çoğunluğunun az sayıda hastayla yapılmış kanıt seviyesi düşük çalışmalar olması, bu yaralanmaların tedavisiyle ilgili hala standart bir tedavi protokolünün oluşturulmasına engel olmaktadır. Daha kesin sonuçların elde edilmesi için çok sayıda hastayla yapılmış, prospektif, randomize klinik çalışmalara ihtiyaç vardır.

\section{KAYNAKLAR}

1. Mazzocca AD, Arciero RA, Bicos J. Evaluation and treatment of acromioclavicular joint injuries. Am J Sports Med 2007;35(2):316-29. Crossref

2. Klonz A, Loitz D. The acromioclavicular joint. Unfallchirurg 2005;108(12):1049-58. Crossref

3. Ceccarelli E, Bondì R, Alviti F, Garofalo R, Miulli F, Padua R. Treatment of acute grade III acromioclavicular dislocation: a lack of evidence. J Orthop Traumatol 2008;9(2):105-8. Crossref

4. Boileau P, Gastaud O, Wilson A, Trojani C, Bronsard N. Allarthroscopic reconstruction of severe chronic acromioclavicular joint dislocations. Arthroscopy 2019;35(5):1324-35. Crossref

5. Martetschläger $F$, Tauber $M$, Habermeyer $P$, Hawi $N$. Arthroscopically assisted acromioclavicular and coracoclavicular ligament reconstruction for chronic acromioclavicular joint instability. Arthrosc Tech 2016;5:e1239-46. Crossref

6. ElMaraghy AW, Devereaux MW, Ravichandiran K, Agur AM. Subacromial morphometric assessment of the clavicle hook plate. Injury 2010;41(6):613-9. Crossref

7. Leidel BA, Braunstein V, Kirchhoff C, Pilotto S, Mutschler W, Biberthaler P. Consistency of long-term outcome of acute Rockwood grade III acromioclavicular joint separations after K-wire transfixation. J Trauma 2009;66:1666-71. Crossref 
8. Tsou PM. Percutaneous cannulated screw coracoclavicular fixation for acute acromioclavicular dislocations. Clin Orthop Relat Res 1989;243:112-21. Crossref

9. Struhl S. Double endobutton technique for repair of complete acromioclavicular joint dislocations. Tech Shoulder Elb Surg 2007;8:175-9. Crossref

10. Shin SJ, Kim NK. Complications after arthroscopic coracoclavicular reconstruction using a single adjustable-loop-length suspensory fixation device in acute acromioclavicular joint dislocation. Arthroscopy 2015;31(5):816-24. Crossref

11. Lim YW. Triple endobutton technique in acromioclavicular joint reduction and reconstruction. Ann Acad Med Singap 2008;37:294-9. Crossref

12. Motta P, Maderni A, Bruno L, Mariotti U. Suture rupture in acromioclavicular joint dislocations treated with flip buttons. Arthroscopy 2011;27:294-8. Crossref

13. Barth J, Duparc F, Andrieu K, Duport M, Toussaint B, Bertiaux $\mathrm{S}$, et al. Is coracoclavicular stabilisation alone sufficient for the endoscopic treatment of severe acromioclavicular joint dislocation (Rockwood types III, IV, and V)? Orthop Traumatol Surg Res 2015;101(Suppl 8):S297-303. Crossref

14. Weaver JK, Dunn HK. Treatment of acromioclavicular injuries, especially complete acromioclavicular separation. J Bone Joint Surg Am 1972;54:1187-94. Crossref

15. Pavlik A, Csépai D, Hidas P. Surgical treatment of chronic acromioclavicular joint dislocation by modified Weaver-Dunn procedure. Knee Surg Sports Traumatol Arthrosc. 2001; 9(5):30712. Crossref

16. DeBerardino TM, Pensak MJ, Ferreira J, Mazzocca AD. Arthroscopic stabilization of the acromioclavicular joint using the AC graftrope system. J Should Elb Surg 2010;19(Suppl 2):47-52. Crossref

17. Arrigoni P, Brady PC, Zottarelli L, Barth J, Narbona P, Huberty $D$, et al. Associated lesions requiring additional surgical treatment in grade 3 acromioclavicular joint dislocations. Arthroscopy 2014;30:6-10. Crossref

18. Parnes N, Friedman D, Phillips C, Carey P. Outcome after arthroscopic reconstruction of the coracoclavicular ligaments using a double-bundle coracoid cerclage technique Arthroscopy 2015;31(10):1933-40. Crossref

19. Meislin R, Lowe D, Dai A. Arthroscopic AC/CC joint reconstruction with allograft and suspensory button fixation. NYU Langone Orthopedics 2017. Available from: https://www.vumedi.com.

20. Saccomanno MF, Sircana G, Cardona V, Vismara V, Scaini A, Salvi AG, et al. Biologic and synthetic ligament reconstructions achieve better functional scores compared to osteosynthesis in the treatment of acute acromioclavicular joint dislocation. Knee Surg Sports Traumatol Arthrosc 2021;29(7):2175-93. Crossref

21. El Sallakh SA. Evaluation of arthroscopic stabilization of acute acromioclavicular joint dislocation using the TightRope system. Orthopedics 2012;35:e18-e22. Crossref

22. Lim YW, Sood A, Van Riet RP. Acromioclavicular joint reduction, repair and reconstruction using metallic buttons-early results and complications. Tech Shoulder Elbow Surg 2007;8:213-21. Crossref
23. Thiel E, Mutnal A, Gilot GJ. Surgical outcome following arthroscopic fixation of acromioclavicular joint disruption with the TightRope device. Orthopedics 2011;34:267-74. Crossref

24. Martetschläger F, Horan MP, Warth RJ, Millet PJ. Complications after anatomic fixation and reconstruction of the coracoclavicular ligaments. Am J Sports Med 2013;41:2896-903. Crossref

25. Clavert P, Meyer A, Boyer P, Gastaud O, Barth J, Duparc F, SFA. Complication rates and types of failure after arthroscopic acute acromioclavicular dislocation fxation. Prospective multicentre study of 116 cases. Orthop Traumatol Surg Res 2015;101(Suppl 8):S313-16. Crossref

26. Cook JB, Shaha JS, Rowles DJ, Bottoni CR, Shaha SR, et al. Early failure with single clavicular transosseous coracoclavicular ligament reconstruction. J Shoulder Elbow Surg 2012;21:1746-52. Crossref

27. Walz L, Salzman GM, Fabbro T, Eichhorn S, Imhoff AB. The anatomic reconstruction of acromioclavicular joint dislocations using 2 TightRope devices: A biomechanical study. Am J Sports Med 2008;36:2398-406. Crossref

28. Beris A, Lykissas M, Kostas Agnantis I, Vekris M, Mitsionis G, et al. Management of acute acromioclavicular joint dislocation with a doublebuttonfixation system. Injury 2013;44:288-92. Crossref

29. Sun LJ, Lu D, Tao ZY, Yu XB, Hu W, Ma YF, et al. Analysis of risk factors for loss of reduction after acromioclavicular joint dislocation treated with the suture-button. J Orthop Sci 2019;24(5):817-21. Crossref

30. Li H, Wang C, Wang J, Wu K, Hang D. Restoration of horizontal stability in complete acromioclavicular joint separations: surgical technique and preliminary results. Eur J Med Res 2013;18(1):42. Crossref

31. Theopold J, Schöbel T, Fischer JP, Löffler S, Osterhoff G, Schleifenbaum $S$ et al.Acromioclavicular joint reconstruction: an additional acromioclavicular cerclage does not improve horizontal stability in double coracoclavicular tunnel technique. Knee Surg Sports Traumatol Arthrosc 2019;27(12):382734. Crossref

32. Banfy MB, Uquillas C, Neumann JA, Elattrache NS. Biomechanical evaluation of a single- versus double-tunnel coracoclavicular ligament reconstruction with acromioclavicular stabilization for acromioclavicular joint injuries. Am J Sports Med 2018;46(5):1070-6. Crossref

33. Lim YW. Triple endobutton technique in acromioclavicular joint reduction and reconstruction. Ann Acad Med Singap 2008;37:294-99.

34. Murena L, Vulcano E, Ratti C, Cecconello L, Rolla PR, Surace MF. Arthroscopic treatment of acute acromioclavicular joint dislocation with doubleflip button. Knee Surg Sports Traumatol Arthrosc 2009;17:1511-15. Crossref

35. Milewski MD, Tompkins M, Giugale JM, Carson EW, Miller MD, Diduch DR.Complications related to anatomic reconstruction of the coracoclavicular ligaments. Am J Sports Med 2012;40(7):1628-34. Crossref

36. Wylie JD, Johnson JD, DiVenere J, Mazzoca AD. Shoulder acromioclavicular and coracoclavicular ligament injuries common problems and solutions. Clin Sports Med 2018;37(2)197-207. Crossref 
37. Martetschläger F, Saier T, Weigert A, Herbst E, Winkler M, Henschel J, et al. Efect of coracoid drilling for acromioclavicular joint reconstruction techniques on coracoid fracture risk: a biomechanical study. Arthroscopy 2016;32(6):982-87. Crossref

38. Thangaraju S, Cepni S, Magosch P, Tauber M, Habermeyer $P$, Martetschläger F.Arthroscopically assisted acromioclavicular joint stabilization leads to significant clavicular tunnel widening in the early post-operative period. Knee Surg Sports Traumatol Arthrosc 2019;27(12):3821-6. Crossref

39. Motta P, Marra F, Maderni A, Vasario G, Sisto R, Jawahar M, et al. The long-term efficacy of the GraftRope technique. J Shoulder Elbow Surg 2020;29(10):2143-8. Crossref

40. Nordin JS, Aagaard KE, Lunsjö K. Chronic acromioclavicular joint dislocations treated by the GraftRope device. Acta Orthop 2015;86(2):225-8. Crossref
41. VanSice W, Savoie FH. Arthroscopic reconstruction of the acromioclavicular joint using semitendinosus allograft: technique and preliminary results. Tech Shoulder Elb Surg 2008;9(3):10913. Crossref

42. Zhu Y, Hsueh P, Zeng B, Chai Y, Zhang C, Chen Y, et al. A prospective study of coracoclavicular ligament reconstruction with autogenous peroneus longus tendon for acromioclavicular joint dislocations. J Shoulder Elbow Surg 2018;27(6):e17888. Crossref

43. Cerciello S, Berthold DP, Uyeki C, Kia C, Cote MP, Imhoff AB,et al. Anatomic coracoclavicular ligament reconstruction (ACCR) using free tendon allograft is effective for chronic acromioclavicular joint injuries at mid-term follow-up. Knee Surg Sports Traumatol Arthrosc 2021;29(7):2096-102. Crossref 